\title{
ЕМІСІЙНІ ХАРАКТЕРИСТИКИ ТА ПАРАМЕТРИ ПЛАЗМИ ЛАЗЕРНОГО ФАКЕЛА НА ОСНОВІ ПОЛІКРИСТАЛА CuInSe
}

\author{
М.П. ЧУЧМАН, Г.Е. ЛАСЛОВ, А.К. ШУАІБОВ, Л.Л. ШИМОН
}

УДК 533.9

Ужгородський національний університет

(Вул. Підгірна 46, Уэсгород 88 000, Україна; e-mail: shuaibоv@univ. uzhgorod. ua)

\begin{abstract}
Отримано спектри випромінювання та осцилограми інтенсивності спектральних ліній лазерної ерозійної плазми на основі сполуки $\mathrm{CuInSe} 2$. Встановлено, що спектри випромінювання з гарячої зони цієї лазерної ерозійної плазми включають спектральні лінії збуджених атомів міді, індію, селену і їх однозарядних іонів. Визначено основні параметри та характеристики лазерного факела на основі сполуки $\mathrm{CuInSe} 2$ : швидкість поширення, часи рекомбінації іонів, температуру та концентрацію частинок. Показано, що на початкових етапах існування плазми основним процесом виступає рекомбінація, а при збільшенні відстані від мішені та часу затримки починають проявлятися газодинамічні та теплові ефекти, які значно визначатимуть особливості формування атомів та іонів у збуджених станах.
\end{abstract}

\section{1. Вступ}

Полікристал $\mathrm{CuInSe} \mathrm{I}_{2}$ найбільш широко використовується у виробництві високоефективних сонячних елементів $[1,2]$. У 2005 році для $\mathrm{CuInSe} 2$ було досягнуто ефективність 19,3\% [3]. Щоб виготовити світлочутливі плівки $\mathrm{CuInSe}_{2}$, використовується складна технологія, тому на даний час $є$ актуальним завдання розвитку більш дешевих, простіших методів виробництва світлочутливих тонких шарів на основі сполуки $\mathrm{CuInSe}_{2}$.

Одним з перспективних методів у формуванні плівок CuInSe 2 є метод лазерного напорошення [4-7]. Властивості тонких плівок, отриманих цим методом, залежать як від умов розпилення вихідного матеріалу, параметрів лазерного випромінювання, так і від температури підкладки. У роботі [8] показано, що покращання радіаційної стійкості світлочутливих плівок при смузі поглинання 0,8-3,5 еВ можливе при використанні сполуки $\mathrm{CuIn}_{3} \mathrm{Se}_{5}$ чи $\mathrm{CuIn}_{5} \mathrm{Se}_{8}$.

Одержані тонкі плівки $\mathrm{CuInSe} 2$ мали хорошу адгезію до підкладки [3]. Дослідження структури плівки при різних температурах показали, що при температурі $T=528-571 \mathrm{~K}$ вони складаються 3 великих ( 100 нм) овальних кристалів. Із збільшенням температури поверхня і висота кристалітів зменшується приблизно в три рази. Зміни форми і розміру кристалітів можуть свідчити про зміну як структури, так і складу плівок $\mathrm{CuInSe}_{2}$ при зміні температури. Зростання фотоелектрорушійної сили при збільшенні температури підкладок від 720 до $770 \mathrm{~K}$ досягає трьох порядків [3].

$\mathrm{У}$ даній роботі проведено емісійну діагностику характеристик та параметрів лазерного факела багатокомпонентного складу для можливості використання таких даних при спектроскопії, аналізі фізикохімічних процесів та оптимізації технологічних процесів з його використанням.

\section{2. Техніка і методика експерименту}

Експерименти проводили 3 використанням імпульсно-періодичного неодимового лазера, який працював у режимі модульованої добротності. Тривалість лазерної генерації становила 20 нс, частота повторення імпульсів - 12 Гц. Фокусування лазерного випромінювання здійснювалося за допомогою лінзи, яка має фокусну відстань 50 см. Фокусуючи лазерне випромінювання у пляму діаметром 0,4-0,5 мм, було отримано на поверхні мішені густину потужності $5 \cdot 10^{8} \mathrm{~B} / \mathrm{cm}^{2}$. У ролі мішені використовували полікристал $\mathrm{CuInSe} 2$. Залишковий тиск повітря у вакуумній камері становив 3-12 Па. Аналіз випромінювання здійснено за допомогою монохроматора МДР-2 з дифракційною граткою (1200 штр/мм) у спектральній області 210-600 нм та фотоелектронного помножувача ФЕУ-106. Відбір випромінювання здійснювали 3 ділянки лазерного факела товщиною 0,3 мм за допомогою лінзи на відстані 1 і 7 мм від мішені.

Усереднені за часом спектри реєстрували з використанням фотоелектронного помножувача ФЕУ-106 і самописця КСП-4. Система ФЕУ-106 і монохроматор МДР-2 калібрувалася за випромінюванням водневої та вольфрамової ламп. Це дозволило виміряти відно- 

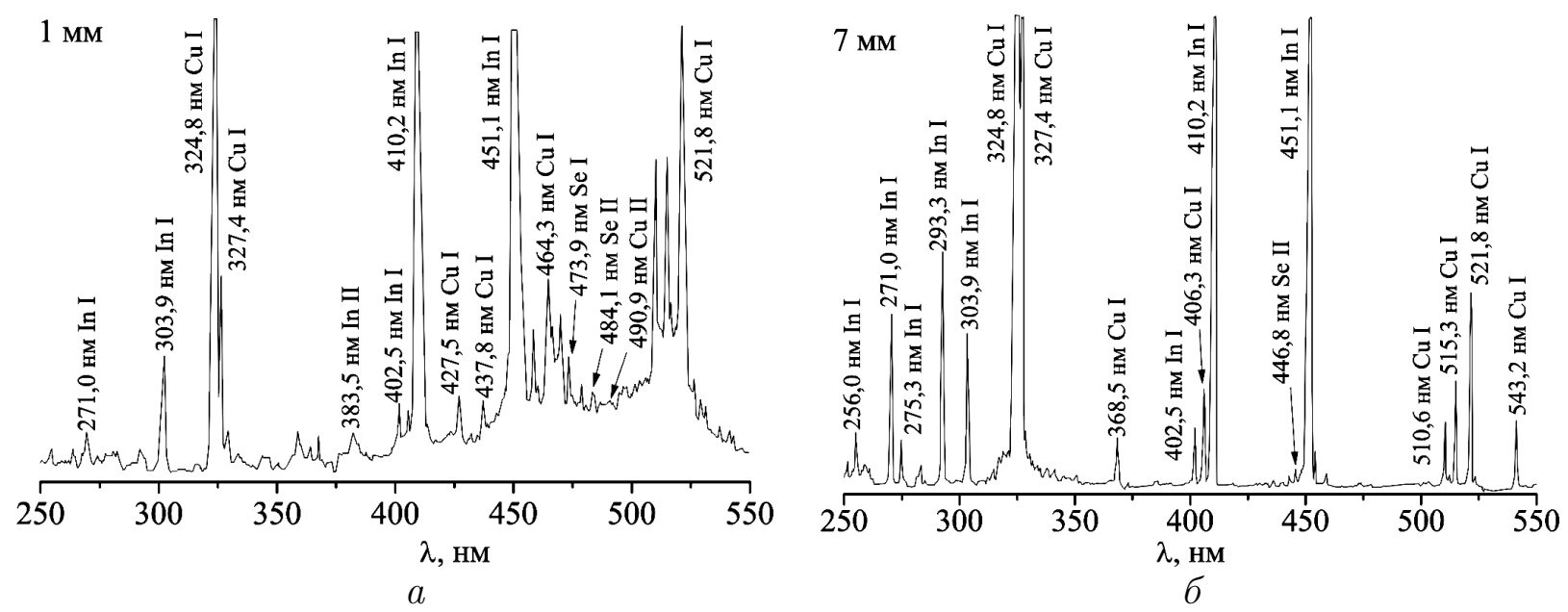

Рис. 1. Спектри випромінювання лазерної ерозійної плазми сполуки $\mathrm{CuInSe} 2$

сні інтенсивності ліній випромінювання $\left(I / k_{\lambda}\right.$, де $k_{\lambda}-$ відносна спектральна чутливість системи реєстрації). Осцилограми інтенсивності спектральних ліній лазерної плазми досліджували за допомогою електронного лінійного помножувача ЕЛУ-14 ФС та осцилографа 6-ЛОР04. Часове розділення становило 2-3 нс.

\section{3. Результати та їх обговорення}

На рис. 1 наведено спектри випромінювання ерозійної плазми сполуки $\mathrm{CuInSe} 2$. Розшифрування спектра наведено в таблиці. Для розшифрування спектра використано дані довідника [9]. У таблиці також наведено: електронну конфігурацію, терм, енергію верхнього збудженого стану, довжину хвилі та інтенсивність випромінювання, усереднену за часом спостереження випромінювання плазми, яка утворюється від одного лазерного імпульсу та пронормована на максимальну інтенсивність лінії з усіх перерахованих при фіксованій відстані від мішені.

Лінійчате випромінювання спостерігалося на фоні неперервного випромінювання. Найбільш інтенсивною була спектральна лінія індію з довжиною хвилі 451,1 нм, її інтенсивність прийнято за одиницю, відповідно для міді максимальна інтенсивність становила 0,96 при довжині хвилі 521,8 нм. Як і очікувалося, найбільш інтенсивними були резонансні лінії атомів міді та індію. Спектральні лінії випромінювання атомів міді розташовані по всьому спектру $(219,9-546,3$ нм), а індію у дещо вужчому спектральному діапазону від 227,8 до 487,8 нм. Спектральні лінії атомів та іонів селену також реєструвалися як слабкі лінії практично по всьому спектральному діапазоні, який досліджувався. Іонна складова подана в основному мід- дю та селеном. Характерним є наявність спектральних ліній іона Se II та відсутність інтенсивних іонних ліній In II. У спектрі випромінювання лазерної плазми на основі цієї сполуки проявляється випромінювання із зміщених станів атомів міді. Найкраще переходи із зміщених станів атомів міді проявлялися в лазерній плазмі на основі чистої речовини міді [10].

Серед найбільш інтенсивних спектральних ліній, за якими можливо проводити діагностику лазерного факела на основі сполуки $\mathrm{CuInSe}_{2}$ (їх інтенсивність більше $20 \%$ від найінтенсивнішої спектральної лінії), можна назвати такі атомарні лінії: 324,$8 ; 327,4 ; 521,8$; 515,$8 ; 515,3 ; 510,6$ нм Cu I та 410,2; 451,1 нм In I на відстані 1 мм від мішені, на відстані 7 мм від мішені - це спектральні лінії 221,6; 271,0; 324,8; 327,4 515,3; 521,$8 ; 543,2$ нм $\mathrm{Cu}$ I та 293,$3 ; 303,9 ; 410,2 ; 451,1$ нм In I.

Якщо енергія верхнього рівня для спектрального переходу атомів індію більша ніж 5 eВ, то інтенсивність випромінювання на відстані 7 мм буде меншою, ніж на відстані 1 мм. Якщо енергія рівня менша за $5 \mathrm{eB}$, то інтенсивність на відстані 7 мм буде більшою, ніж на відстані 1 мм. У випадку атомарних спектральних ліній при збільшенні відстані від мішені терми станів, із яких відбуваються випромінювальні переходи, відповідають нижчим електронним конфігураціям. Найбільша кількість спектральних ліній у спектрі випромінювання належить атомам міді. Більше ніж $60 \%$ з них належить переходам із зміщених станів. Інтенсивність таких спектральних ліній, як правило, не перевищує $10 \%$ від значення інтенсивності найбільш інтенсивної лінії спектра. На відстані 1 мм від мішені спостерігаються три спектральні лінії атомів селену, верхні збуджені стани яких знаходя- 
Розшифровка спектрів випромінювання лазерної плазми на базі сполуки CuInSe 2

\begin{tabular}{|c|c|c|c|c|c|c|c|c|c|c|c|}
\hline$\lambda, \mathrm{HM}$ & Атом, іон & $I_{1}$, в. о. & $I_{7}$, в. о. & $\mathrm{Tepm}_{\mathrm{B}}$ & $E_{\mathrm{B}}, \mathrm{eB}$ & $\lambda$, нм & Атом, іон & $I_{1}$, в. о. & $I_{7}$, в. о. & $\mathrm{Tepm}_{\mathrm{B}}$ & $E_{\mathrm{B}}, \mathrm{eB}$ \\
\hline 219,90 & $\mathrm{Cu} \mathrm{I}$ & - & 0,17 & $\mathrm{~s} 4 \mathrm{p} "{ }^{2} \mathrm{D}_{3 / 2}$ & 7,27 & 435,40 & $\mathrm{Cu} \mathrm{I}$ & 0,03 & - & $\mathrm{s} 5 \mathrm{~s}^{\prime}{ }^{2} \mathrm{D}_{3 / 2}$ & 8,09 \\
\hline 221,60 & $\mathrm{Cu} \mathrm{I}$ & - & 0,27 & $\mathrm{~s} 4 \mathrm{p} "{ }^{2} \mathrm{P}_{3 / 2}$ & 6,98 & 437,80 & $\mathrm{Cu} \mathrm{I}$ & 0,07 & 0,01 & $\mathrm{~s} 5 \mathrm{~s}{ }^{4} \mathrm{D}_{5 / 2}$ & 7,80 \\
\hline 227,80 & In I & - & 0,07 & - & 5,45 & 440,10 & Se II & 0,05 & - & - & 16,2 \\
\hline 252,20 & In I & 0,03 & 0,05 & $7 \mathrm{~d}^{2} \mathrm{D}_{5 / 2}$ & 5,19 & 441,60 & $\mathrm{Cu} \mathrm{I}$ & 0,05 & 0,01 & $\mathrm{~s} 5 \mathrm{~s}{ }^{4} \mathrm{D}_{3 / 2}$ & 7,88 \\
\hline 256,00 & In I & 0,04 & 0,10 & $6 \mathrm{~d}^{2} \mathrm{D}_{3 / 2}$ & 4,84 & 444,60 & Se II & 0,06 & 0,02 & - & 15,05 \\
\hline 259,30 & $\mathrm{Cu} \mathrm{I}$ & 0,02 & 0,04 & - & - & 446,80 & Se II & - & 0,03 & - & 15,03 \\
\hline 260,20 & In I & 0,03 & - & $8 \mathrm{~s}^{2} \mathrm{~S}_{1 / 2}$ & 5,03 & 448,00 & $\mathrm{Cu} \mathrm{I}$ & 0,09 & - & $6 \mathrm{~s}^{2} \mathrm{~S}_{1 / 2}$ & 6,55 \\
\hline 261,80 & $\mathrm{Cu} \mathrm{I}$ & 0,02 & 0,03 & $5 \mathrm{p}^{2} \mathrm{P}_{3 / 2}$ & 6,12 & 451,10 & In I & 1,00 & 1,00 & $6 \mathrm{~s}^{2} \mathrm{~S}_{1 / 2}$ & 3,02 \\
\hline 262,70 & $\mathrm{Cu} \mathrm{I}$ & 0,02 & - & $\mathrm{s} 5 \mathrm{~d}{ }^{4} \mathrm{D}_{3 / 2}$ & 9,79 & 454,00 & $\mathrm{Cu} \mathrm{I}$ & - & 0,03 & $\mathrm{~s} 5 \mathrm{~s}{ }^{4} \mathrm{D}_{3 / 2}$ & 7,88 \\
\hline 264,50 & $\mathrm{Cu} \mathrm{I}$ & 0,04 & - & $\mathrm{s} 5 \mathrm{~d}{ }^{4} \mathrm{D}_{5 / 2}$ & 9,65 & 458,70 & $\mathrm{Cu} \mathrm{I}$ & 0,18 & 0,03 & $\mathrm{~s} 5 \mathrm{~s}{ }^{4} \mathrm{D}_{5 / 2}$ & 7,80 \\
\hline 271,00 & In I & 0,05 & 0,26 & $6 \mathrm{~d}^{2} \mathrm{D}_{5 / 2}$ & 4,84 & 461,20 & In I & 0,11 & - & - & - \\
\hline 275,30 & In I & 0,03 & 0,07 & $7 \mathrm{~s}^{2} \mathrm{~S}_{1 / 2}$ & 4,50 & 464,30 & $\mathrm{Cu} \mathrm{I}$ & 0,27 & - & $\mathrm{s} 5 \mathrm{~s}^{\prime}{ }^{2} \mathrm{D}_{3 / 2}$ & 8,09 \\
\hline 277,50 & In I & 0,03 & - & $\mathrm{s} 5 \mathrm{p}^{2}{ }^{4} \mathrm{P}_{3 / 2}$ & 4,46 & 467,50 & $\mathrm{Cu} \mathrm{I}$ & 0,21 & - & $\mathrm{s} 5 \mathrm{~s}{ }^{4} \mathrm{D}_{5 / 2}$ & 7,80 \\
\hline 282,40 & $\mathrm{Cu} \mathrm{I}$ & 0,03 & 0,02 & $\mathrm{~s} 4 \mathrm{p}{ }^{2} \mathrm{D}_{5 / 2}$ & 5,77 & 469,70 & $\mathrm{Cu} \mathrm{I}$ & 0,23 & - & $\mathrm{s} 5 \mathrm{~s}{ }^{4} \mathrm{D}_{3 / 2}$ & 7,88 \\
\hline 283,70 & In I & 0,03 & 0,03 & $\mathrm{~s} 5 \mathrm{p}^{2}{ }^{4} \mathrm{P}_{5 / 2}$ & 4,64 & 473,90 & Se I & 0,17 & - & $6 \mathrm{p}^{5} \mathrm{P}_{2}$ & 8,59 \\
\hline 293,30 & In I & 0,04 & 0,33 & $7 \mathrm{~s}^{2} \mathrm{~S}_{1 / 2}$ & 4,50 & 474,20 & Se I & 0,11 & - & $6 \mathrm{p}^{5} \mathrm{P}_{1}$ & 8,59 \\
\hline 303,90 & In I & 0,14 & 0,23 & $5 \mathrm{~d}^{2} \mathrm{D}_{3 / 2}$ & 4,07 & 479,40 & $\mathrm{Cu} \mathrm{I}$ & 0,14 & - & - & 8,09 \\
\hline 315,70 & $\mathrm{Cu} \mathrm{I}$ & - & 0,03 & $\mathrm{~s} 4 \mathrm{p} \cdot{ }^{4} \mathrm{D}_{1 / 2}$ & 5,56 & 481,30 & $\mathrm{Cu}$ II & 0,10 & - & $4 \mathrm{f}^{1} \mathrm{D}_{2}$ & 17,1 \\
\hline 317,00 & $\mathrm{Cu} \mathrm{I}$ & - & 0,05 & $\mathrm{~s} 4 \mathrm{~d}{ }^{\prime}{ }^{4} \mathrm{G}_{7 / 2}$ & 9,06 & 484,10 & Se II & 0,13 & - & $5 \mathrm{p}^{2} \mathrm{~S}_{1 / 2}^{0}$ & 14,5 \\
\hline 319,40 & $\mathrm{Cu} \mathrm{I}$ & - & 0,06 & $\mathrm{~s} 4 \mathrm{p}{ }^{4} \mathrm{D}_{3 / 2}$ & 5,52 & 487,80 & In I & 0,11 & - & - & 5,56 \\
\hline 322,30 & $\mathrm{Cu} \mathrm{I}$ & - & 0,05 & $\mathrm{~s} 4 \mathrm{~d}^{\prime}{ }^{4} \mathrm{~F}_{3 / 2}$ & 9,09 & 490,96 & $\mathrm{Cu} \mathrm{II}$ & 0,12 & - & $4 \mathrm{f}^{3} \mathrm{H}_{6}$ & 16,8 \\
\hline 324,80 & $\mathrm{Cu} \mathrm{I}$ & 0,81 & 0,98 & $4 p^{2} \mathrm{P}_{3 / 2}$ & 3,81 & 493,20 & $\mathrm{Cu} \mathrm{II}$ & 0,11 & - & $4 \mathrm{f}^{3} \mathrm{H}_{5}$ & 16,8 \\
\hline 327,40 & $\mathrm{Cu} \mathrm{I}$ & 0,21 & 0,82 & $4 p^{2} \mathrm{P}_{1 / 2}$ & 3,78 & 495,40 & $\mathrm{Cu} \mathrm{II}$ & 0,14 & - & $4 \mathrm{f}^{1} \mathrm{H}_{5}$ & 17,1 \\
\hline 329,30 & $\mathrm{Cu} \mathrm{I}$ & 0,05 & 0,08 & $\mathrm{~s} 4 \mathrm{~d}^{\prime}{ }^{4} \mathrm{P}_{3 / 2}$ & 8,91 & 497,60 & Se II & 0,14 & - & $5 p^{2} \mathrm{D}_{5 / 2}^{0}$ & 14,93 \\
\hline 331,70 & $\mathrm{Cu} \mathrm{I}$ & - & 0,05 & $\mathrm{~s} 4 \mathrm{~d}^{\prime}{ }^{4} \mathrm{~F}_{9 / 2}$ & 8,83 & 499,30 & Se II & 0,14 & - & $5 p^{4} \mathrm{P}_{3 / 2}^{0}$ & 14,48 \\
\hline 333,50 & $\mathrm{Cu} \mathrm{I}$ & 0,03 & 0,04 & $\mathrm{~s} 4 \mathrm{~d}^{\prime}{ }^{2} \mathrm{~F}_{7 / 2}$ & 8,81 & 501,70 & $\mathrm{Cu} \mathrm{I}$ & 0,15 & - & $\mathrm{s} 5 \mathrm{~s}{ }^{4} \mathrm{D}_{1 / 2}$ & 7,99 \\
\hline 335,40 & $\mathrm{Cu} \mathrm{I}$ & - & 0,03 & $\mathrm{~s} 4 \mathrm{~d}^{\prime}{ }^{2} \mathrm{D}_{3 / 2}$ & 8,94 & 503,40 & $\mathrm{Cu} \mathrm{I}$ & 0,15 & - & $\mathrm{s} 5 \mathrm{~s}{ }^{4} \mathrm{D}_{3 / 2}$ & 7,88 \\
\hline 336,50 & $\mathrm{Cu} \mathrm{I}$ & - & 0,03 & $\mathrm{~s} 4 \mathrm{~d}^{\prime}{ }^{2} \mathrm{G}_{9 / 2}$ & 8,78 & 505,20 & $\mathrm{Cu} \mathrm{II}$ & 0,16 & - & $4 \mathrm{f}^{3} \mathrm{G}_{5}$ & 16,8 \\
\hline 337,60 & $\mathrm{Cu} \mathrm{I}$ & - & 0,03 & $\mathrm{~s} 4 \mathrm{~d}^{\prime}{ }^{4} \mathrm{P}_{5 / 2}$ & 8,82 & 507,60 & $\mathrm{Cu} \mathrm{I}$ & 0,16 & - & $\mathrm{s} 5 \mathrm{~s}^{\prime}{ }^{2} \mathrm{D}_{5 / 2}$ & 8,01 \\
\hline 341,30 & $\mathrm{Cu} \mathrm{I}$ & - & 0,03 & $\mathrm{~s} 4 \mathrm{~d}^{\prime 2} \mathrm{P}_{1 / 2}$ & 9,31 & 510,60 & $\mathrm{Cu} \mathrm{I}$ & 0,56 & 0,15 & $4 p^{2} \mathrm{P}_{3 / 2}$ & 3,81 \\
\hline 345,00 & $\mathrm{Cu} \mathrm{I}$ & 0,02 & - & - & 9,37 & 511,90 & $\mathrm{Cu} \mathrm{I}$ & - & 0,03 & - & 7,99 \\
\hline 351,20 & $\mathrm{Cu} \mathrm{I}$ & 0,02 & 0,02 & $\mathrm{~s} 4 \mathrm{~d}^{\prime}{ }^{4} \mathrm{G}_{9 / 2}$ & 8,92 & 515,30 & $\mathrm{Cu} \mathrm{I}$ & 0,58 & 0,25 & $4 \mathrm{~d}^{2} \mathrm{D}_{3 / 2}$ & 6,19 \\
\hline 359,40 & $\mathrm{Cu} \mathrm{I}$ & 0,05 & - & $\mathrm{s} 4 \mathrm{p} \cdot{ }^{4} \mathrm{P}_{5 / 2}$ & 4,83 & 515,80 & $\mathrm{Cu} \mathrm{I}$ & 0,31 & - & - & 8,09 \\
\hline 364,50 & $\mathrm{Cu} \mathrm{I}$ & 0,03 & - & $\mathrm{s} 4 \mathrm{~d}{ }^{4} \mathrm{~F}_{5 / 2}$ & 9,08 & 517,60 & Se II & 0,27 & - & $5 \mathrm{p}^{4} \mathrm{D}_{5 / 2}^{0}$ & 14,39 \\
\hline 368,50 & $\mathrm{Cu} \mathrm{I}$ & 0,04 & 0,06 & - & 8,82 & 521,80 & $\mathrm{Cu} \mathrm{I}$ & 0,96 & 0,45 & $4 d^{2} D_{5 / 2}$ & 6,19 \\
\hline 383,50 & In II & 0,04 & - & - & 21,1 & 522,80 & Se II & - & 0,03 & $5 \mathrm{p}^{4} \mathrm{D}_{7 / 2}^{0}-$ & 14,6 \\
\hline 387,70 & Se II & 0,02 & - & - & 15,7 & 525,40 & In I & 0,16 & - & - & 5,38 \\
\hline 402,30 & $\mathrm{Cu} \mathrm{I}$ & 0,06 & 0,08 & $5 \mathrm{~d}^{2} \mathrm{D}_{3 / 2}$ & 6,86 & 526,30 & In I & 0,18 & - & - & 5,38 \\
\hline 406,30 & $\mathrm{Cu} \mathrm{I}$ & 0,05 & 0,12 & $5 \mathrm{~d}^{2} \mathrm{D}_{5 / 2}$ & 6,86 & 529,30 & $\mathrm{Cu} \mathrm{I}$ & 0,14 & - & $\mathrm{s} 5 \mathrm{~s}{ }^{\prime}{ }^{4} \mathrm{D}_{7 / 2}$ & 7,73 \\
\hline 410,20 & In I & 0,69 & 0,74 & $6 \mathrm{~s}^{2} \mathrm{~S}_{1 / 2}$ & 3,02 & 531,60 & $\mathrm{Cu} \mathrm{II}$ & 0,12 & - & $5 \mathrm{~d}^{3} \mathrm{D}_{1}$ & 17,2 \\
\hline 418,10 & $\mathrm{Cu}$ II & 0,03 & - & - & 17,5 & 537,40 & Se I & 0,09 & - & $6 \mathrm{p}^{3} \mathrm{P}_{1}$ & 8,63 \\
\hline 423,10 & $\mathrm{Cu} \mathrm{I}$ & 0,03 & - & s5s" ${ }^{2} D_{5 / 2}$ & 8,32 & 540,80 & $\mathrm{Cu} \mathrm{I}$ & 0,08 & - & - & 8,02 \\
\hline 424,90 & $\mathrm{Cu} \mathrm{I}$ & 0,04 & - & $\mathrm{s} 5 \mathrm{~s}^{\prime}{ }^{4} \mathrm{D}_{1 / 2}$ & 7,99 & 543,20 & $\mathrm{Cu} \mathrm{I}$ & 0,07 & 0,20 & $\mathrm{~s} 5 \mathrm{~s}^{\prime}{ }^{4} \mathrm{D}_{5 / 2}$ & 7,80 \\
\hline 427,50 & $\mathrm{Cu} \mathrm{I}$ & 0,08 & - & $\mathrm{s} 5 \mathrm{~s}^{\prime}{ }^{4} \mathrm{D}_{7 / 2}$ & 7,73 & 546,30 & $\mathrm{Cu} \mathrm{I}$ & 0,04 & - & $\mathrm{s} 5 \mathrm{~s}^{\prime}{ }^{4} \mathrm{D}_{1 / 2}$ & 7,99 \\
\hline 432,90 & Se I & 0,04 & - & - & 9,18 & & & & & & \\
\hline
\end{tabular}

ться в діапазоні енергій 8,59-8,63 еВ. На відстані 7 мм від мішені спектральні лінії атомів селену зникають, як і випромінювання іонів індію. Зафіксованій спе- ктральній лінії іона індію відповідає енергія верхнього енергетичного рівня 21,11 еВ. Для іонів міді спостерігаються спектральні лінії на переходах із верхніх 
збуджених станів у діапазоні енергій 16,85 і 17,22 еВ. Для атомів та іонів селену на відстані 1 мм від мішені спостерігаються спектральні лініі, які відповідають переходам із енергетичних рівнів у діапазоні енергій 14,39 і 16,26 еВ. На відстані 7 мм від мішені спостерігаються спектральні лінії іонів селену при переходах із іще вужчого діапазону енергій верхніх рівнів 14,615,05 еВ. Такі особливості свідчать про наявність специфіки утворення верхніх збуджених станів атомів та іонів, найбільш імовірно пов'язаної із механізмом атомізації мішені та проявом фізико-хімічних процесів у лазерній плазмі.

3 рис. 2 випливає, що осцилограми випромінювання характеризуються двома максимумами. Перший спостерігається при часі 10-14 нс для індію і 13-18 нс для міді, а другий - при часі 56-85 нс і 82-85 нс відповідно. Оцінена з цих даних середня швидкість руху першого максимуму частинок різних компонент плазми становить 83 і 63 км/с, відповідно, для індію і міді. Для другого максимуму швидкість відрізняється менше і становить 14 і $12 \mathrm{~km} /$ с для індію і міді.

Таким чином, можна відзначити, що в центрі лазерного факела більше міді, а на периферії більше індію. 3 часом дисперсія різних елементів багатокомпонентної плазми зменшується. Тут потрібно відзначити вплив газодинамічних ефектів і необхідність хімічно активного або неактивного газу у вакуумній камері. Підбором тиску цього газу можливо коректувати хімічний склад конденсату (за допомогою хімічних реакцій у газовій фазі та на поверхні), його структуру (за допомогою зміни енергії рухомих частинок при взаємодії із зовнішнім газом), а також дисперсію різних елементів плазми [11].

Перший максимум інтенсивності випромінювання спектральних ліній на осцилограмах (рис. 2) виявляється тим краще і тим більша його інтенсивність, чим вища енергія верхнього збудженого стану для спектральної лінії, що випромінюється атомом. Даний ефект однаково виражений як для спектральних ліній міді, так і індію. Тривалість випромінювання спектральних ліній зменшується з ростом енергії верхнього рівня. Найбільш інтенсивним у спектрі було випромінювання спектральних ліній атомів міді та індію. Необхідно зазначити, що найбільша інтенсивність у першому максимумі притаманна спектральній лінії атома індію, а у другому максимумі - спектральній лініі атома міді. Для селену в спектрі випромінювання присутні тільки відносно дуже слабкі лінії, для яких нам не вдалося отримати чітких осцилограм. Їх інтенсивність значно нижча

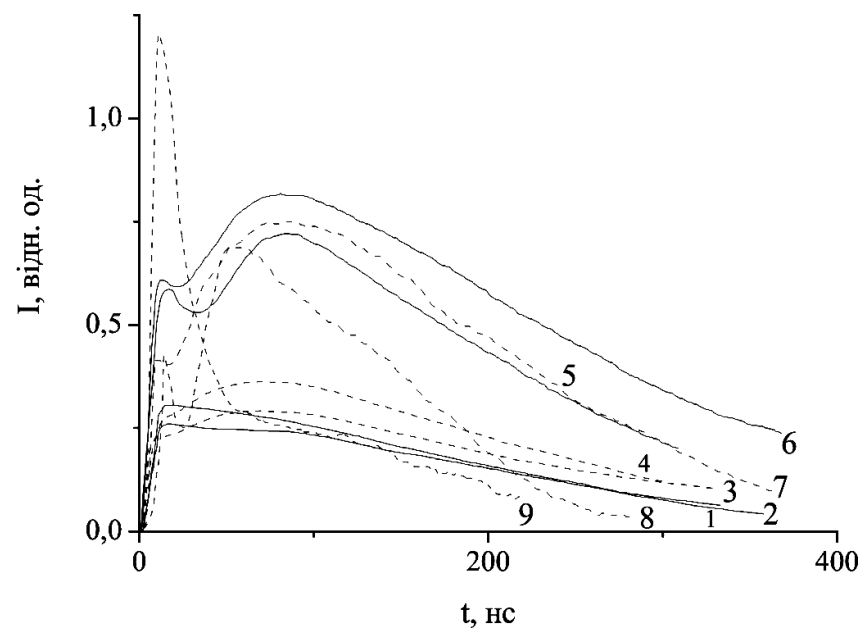

Рис. 2. Осцилограми випромінювання лазерної ерозійної плазми на основі CuInSe 2 на відстані 1 мм від мішені: 1 - 521,8 нм $\mathrm{Cu}$ I; 2 - 515,3 нм Cu I; 3 - 410,2 нм In I; 4 - 451,1 нм In I; 5 327,4 нм Cu I; $6-324,8$ нм Cu I; $7-303,9$ нм In I; $8-293,3$ нм In I; $9-271$ нм In I

за інтенсивність випромінювання атомів міді або індію.

Судячи з осцилограм випромінювання спектральних ліній, ми можемо зробити висновок про те, що при часі появи першого максимуму домінують процеси тричастинкової рекомбінації, а при часі появи другого максимуму переважає збудження при зіткненнях $з$ тепловими електронами плазми, які одержують енергію частково і за рахунок передачі їм енергії у процесі рекомбінації на початкових етапах існування плазми [12].

За часом спостереження випромінювання, беручи до уваги середню швидкість руху плазми, можемо оцінити розміри плазмового факела, який рухається через зону відбору випромінювання. На відстані 1 мм від мішені поздовжній розмір плазми має величину близько 10 мм. Виходячи з того, що випромінювання спостерігається набагато довше, ніж час дії лазера на мішень $t_{\text {las }}$, необхідно відзначити значне розширення плазми під час руху на близьких відстанях до мішені та можливість випаровування мішені довший час, ніж $t_{\text {las }}$.

На рис. 3 показано швидкості зміни інтенсивності для спектральних ліній, що досліджувалися. 3 нього випливає, що для атома індію розкид швидкості зміни інтенсивності при переходах з рівнів різних енергій більший, ніж для міді.

Найшвидше змінюється інтенсивність спектральних ліній на переходах з високозбуджених станів атомів міді і індію. Знайдені з цих даних значення часів 

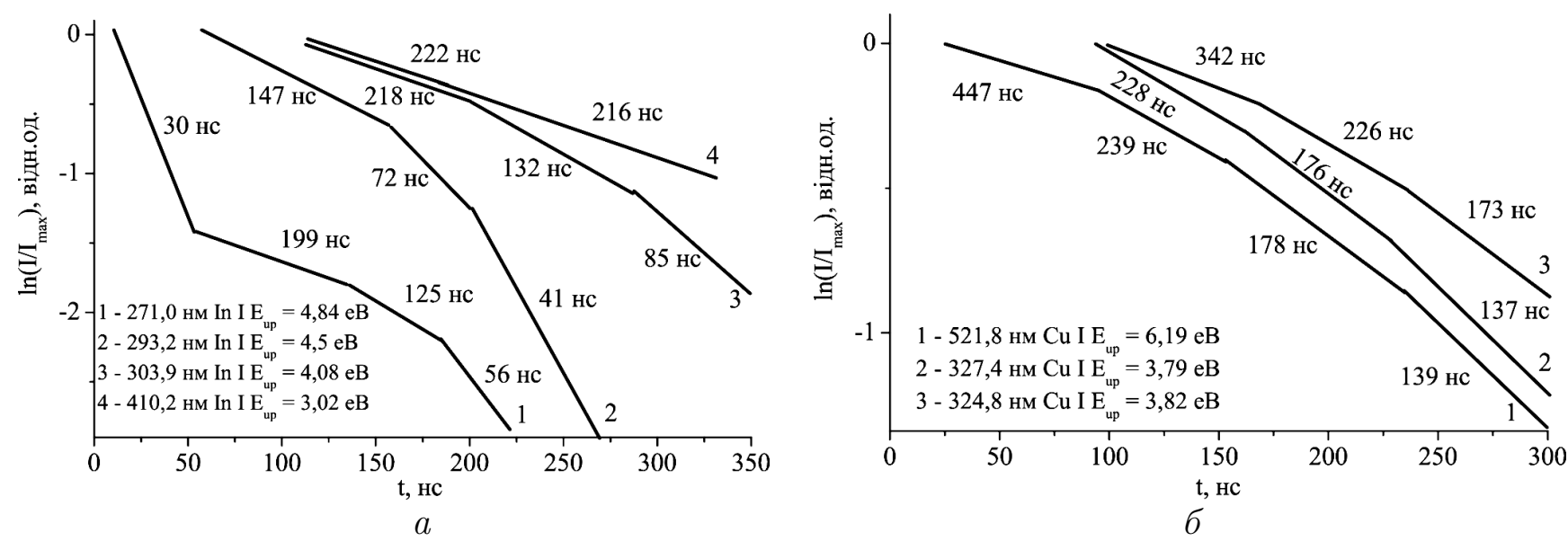

Рис. 3. Порівняння швидкості зміни інтенсивності випромінювання спектральних ліній лазерної ерозійної плазми на основі сполуки CuInSe2 на відстані 1 мм від мішені

рекомбінації для однозарядних іонів індію становлять 30 нс при часі спостереження 25-50 нс і 56 нс при часі спостереження близько 200 нс. Час рекомбінації відповідних іонів міді, що випливає з рис. 3, набагато більший. Він становив 139 нс для часового інтервалу 250-300 нс.

Таким чином, можна зазначити, що більша кількість іонізованих частинок міді, які потрапляють на підкладку, сприятиме її ефективнішому впровадженню у структуру плівки через більшу рухливість, що вноситься енергією високозбуджених і іонізованих частинок. Це повинно ще більше згладжувати просторову дисперсію елементів матеріалу мішені, оскільки у випадку індію кінетична енергія рухомих частинок більша, а кількість іонізованих частинок менша. Цьому сприяє знаходження індію на периферії плазмового факела, де температура і концентрація електронів менші, мідь же, у свою чергу, знаходиться ближче до центра плазмового факела, де температура вища. Крім того, для міді в лазерному факелі характерне утворення автоіонізаційних станів, час теплової і випромінювальної релаксації яких значно більший, ніж для незміщених одноелектронних збуджених станів. Тому, зазвичай, заселеності таких станів з часом можуть значно переважати заселеності незміщених збуджених станів з одноелектронним збудженням.

Із рис. 3 випливає, що ефективність утворення нижніх збуджених станів атомів індію зростає. При часі 100-200 нс швидкість зміни інтенсивності при переходах з низькоенергетичних станів більша у індію, а при часі 200-300 нс швидкість зміни інтенсивності при переходах з низькоенергетичних станів більше у міді. Це свідчить про переважання рекомбінаційних процесів збудження на передньому фронті плазми і збудження під час зіткнень з вільними електронами на задньому фронті плазми. Це також викликає перерозподіл енергії збудження між частинками різних сортів у лазерному факелі.

3 рис. 4 випливає, що температура електронів змінюється 3 відстанню 1-7 мм незначно (від 0,7 до 0,8 еВ). Збільшення температури при поширенні плазми можна пояснити впливом газодинаміки розширення на параметри плазми. Якщо на близьких відстанях плазма розширюється, то на великих навпаки поступово стискуватиметься внаслідок накопичення частинок біля фронту ударної хвилі, який поступово зменшує швидкість руху плазми. Тому основна маса матеріалу буде з часом його наздоганяти. Із газових законів випливає, що температура за таких умов зростає.

Також можна відзначити, що концентрації атомів в основному стані відрізняються набагато більше, ніж концентрації іонів в основному стані. Це можна проілюструвати порівнянням величини заселеності різних атомів на рис. 4 при енергії їх іонізації. Енергія, яка вноситься в мішень, достатня для майже повної іонізації речовини матеріалу, що видаляється з мішені. За оцінками для чистої речовини міді та індію величина питомої потужності при наших умовах, яка необхідна для повної іонізації речовини мішені, становить $10,7 \cdot 10^{8}$ та $2,2 \cdot 10^{8} \mathrm{~B}$ т $/ \mathrm{cm}^{2}$ відповідно. 3 цього випливає, що незважаючи на відсутність даних для селену та високу імовірність перебування селену у вигляді комплексів внаслідок хімічних реакцій на пізніх стадіях існування плазми, стехіометрія плівки, яка одержуватиметься із неї, повинна, в цілому, відповідати стехіометрії мішені. Більш ретельної уваги під час одержання плівки вимагатиме однорідність $\dddot{1}$ 
складу і структури за площею та об'ємом. На початкових етапах існування плазма буде майже повністю складатися з однозарядних іонів [11]. Динаміка руху плазми та специфіка перебігу рекомбінаційних процесів при цьому буде визначати кількість іонізованих частинок, які дістануться підкладки та вноситимуть додаткову, необхідну для одержання впорядкованої структури плівки, енергію. Одержання інформації про енергобаланс плазми на пізніх стадіях розльоту дає інформацію про необхідність додаткового термічного впливу на підкладку, де формується плівка, у випадку, коли відстань їі розташування від мішені буде такою, що енергії внесеної швидкими та іонізованими частинками буде недостатньо для формування кристалічної структури плівки, для якої показано найкращі значення фотоелектричного перетворення.

Основна причина появи першого максимуму на осцилограмах випромінювання лазерної плазми - це атомізація і збудження атомів мішені. А другий максимум спричинений тепловими процесами, які відбуваються під час розлітання переднього фронту плазми у навколишній газ і взаємодії рухомих частинок плазми з атомами оточуючого газу.

Оскільки потужність лазерного випромінювання достатня для атомізації мішені, тому у лазерній плазмі можливі комплекси атомів $\mathrm{Cu}-\mathrm{Se}, \mathrm{In}-\mathrm{Se}, \mathrm{Cu}-$ In-Se, розпад яких у різних частинах плазми в piзні просторово-часові інтервали також спричинятиме утворення збуджених станів атомів та іонів. Про це свідчить, зокрема, утворення іонів у вузькому енергетичному проміжку збуджених станів та спостереження випромінювання атомів або іонів халькогену лише короткий час порівняно з іншими складовими плазми.

Концентрація електронів на відстані 1 мм від мішені в лазерній плазмі на основі сполуки $\mathrm{CuInSe} 2$ становить $2,8 \cdot 10^{16} \mathrm{~cm}^{-3}$, що вище, ніж у відповідної сполуки із сіркою $\left(2,2 \cdot 10^{16} \mathrm{~cm}^{-3}[13]\right)$. Основною причиною цього є відмінності в енергії атомізації даних сполук та менша енергія іонізації атомів селену, оскільки відомо, що енергія розриву зв'язків із сіркою вища, ніж енергія розриву зв'язків із селеном, що відображається також і на величині забороненої зони сполук селенідів та сульфідів.

\section{4. Висновки}

Найбільш інтенсивні спектральні лінії, що випромінюються плазмою лазерного факела на основі сполуки $\mathrm{CuInSe}$, належать атомам індію і міді $(271,0$;

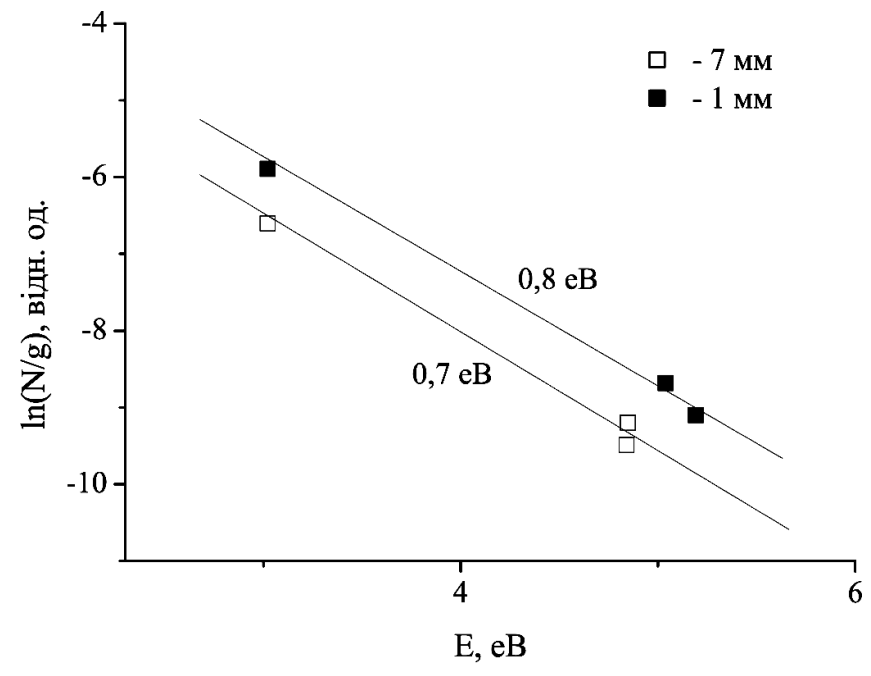

Рис. 4. Температура електронів у лазерній плазмі на основі сполуки $\mathrm{CuInSe}_{2}$ визначена грунтуючись на розподілі заселеностей збуджених станів атомів індію

293,3; 303,9; 410,2; 451,1 нм In I i 324,8; 327,4; 521,8 нм $\mathrm{Cu} \mathrm{I})$. Вигляд осцилограм інтенсивності випромінювання спектральних ліній представляе два максимуми: перший найбільш виражений для переходів з високозбуджених станів атомів, другий - для переходів з низькоенергетичних рівнів. Середня швидкість руху першого максимуму частинок різних компонент плазми становить 83 і $63 \mathrm{~km} /$ с для індію і міді, а для другого максимуму - 14 і 12 км/с відповідно. Значення часу рекомбінації для однозарядних іонів індію становить 30 нс при часі спостереження 25-50 нс і 56 нс при часі спостереження $\approx 200$ нс. Час рекомбінації відповідних іонів міді становить 139 нс для часового інтервалу 250-300 нс. У плазмі лазерного факела характерна перевага рекомбінаційних процесів утворення збуджених частинок на передньому фронті і поступовий перехід до переваги збудження при зіткненнях з вільними електронами на задньому фронті. Температура електронів змінюється з відстанню 17 мм незначно від 0,7 до 0,8 еВ. Збільшення температури при поширенні плазми викликане впливом газодинаміки розширення на параметри плазми: якщо на близьких відстанях плазма розширюється, то на великих, навпаки - поступово стискуватиметься внаслідок накопичення частинок біля фронту ударної хвилі. Концентрація електронів на відстані 1 мм від мішені в лазерній плазмі на основі сполуки $\mathrm{CuInSe} 2$ становить $2,8 \cdot 10^{16} \mathrm{~cm}^{-3}$. Вивчення параметрів та просторових характеристик плазми дає необхідну інформацію про її енергетичний та компонентний склад, що є визначальним при формуванні тонких плівок робочих 
елементів фотоелектричних перетворювачів з необхідною структурою та стехіометрією.

Робота виконана за підтримки Державного Фонду Фундаментальних Досліджень України та Державного комітету України з питань науки, інновацій та інформатизації (проект №Ф29.1/041).

1. I.V. Bodnar and V.F. Gremenok, Appl. Spectr. 74, 90 (2007)

2. А.Г. Гусейнов, В.И. Тагиров, Заак Хосин, Деббаш Джамель, Д.А. Талыбова, ВИНИТИ “Депонированные научные работы", 9, 141, (1990).

3. Ya. Vertsimakha, Ya.P. Lutsuk, O. Lytvyn, and P. Gashin, Ukr. Phys. J. 52, 399 (2007).

4. А. Роуз, Основы теории фотопроводимости (Мир, Москва, 1966).

5. Е.П. Зарецкая, И.Д. Викторов, В.Ф. Гременок, Д.В. Мудрый, ПЖТФ 27, 17 (2001).

6. А.Г. Гусейнов, Д.А. Талыбова, Заак Хосин, Деббаш Джамель, ВИНИТИ “Депонированные научные работы”, № 1472-Аз, 6 (1991).

7. O. Aissaoui, S. Mehdaoui, L. Bechiri, M. Benabdeslem, N. Benslim, A. Amara, L. Mahdjoubi, and G. Nouet, J. Phys. D: Appl. Phys. 40, 5663,(2007).

8. И.В. Боднарь, В.Ф. Гременок, Ю.Л. Николаев, В.Ю. Рудь, Ю.В. Рудь, Е.И. Теруков, ПЖТФ 33 , 32 (2007)

9. P.L. Smith, C. Heise, J.R. Esmond, and R.L. Kurucz, Atomic spectral line database from CD-ROM 23 of R.L. Kurucz (Smithsonian astrophysical observatory, Cambridge, 1995); http://cfa-www.harvard.edu/amp.

10. М.П. Чучман, А.К. Шуаібов, УФЖ 53, 772 (2008).

11. М.П. Чучман, А.К. Шуаибов, Г.Е. Ласлов, ПЖТФ 35 , $51(2009)$.

12. Л.Л. Шимон, Я.М. Семенюк, А.Й. Дащенко, Фізика плазми (Говерла, Ужгород, 2009).

13. О.К. Шуаібов, М.П. Чучман, Л.Л. Шимон, І.Є. Качер, УФЖ 48, 223 (2003).

Одержано 02.04.11

\section{ЭМИССИОННЫЕ ХАРАКТЕРИСТИКИ И ПАРАМЕТРЫ ПЛАЗМЫ ЛАЗЕРНОГО ФАКЕЛА НА ОСНОВЕ ПОЛИКРИСТАЛЛА CuInSe 2}

М.П. Чучман, Г.Е. Ласлов, А.К. Шуаибов, Л.Л. Шимон

$\mathrm{P}$ е $з$ ю м е

Исследованы спектры излучения и осциллограммы интенсивности спектральных линий лазерной эрозийной плазмы на основе соединения $\mathrm{CuInSe}_{2}$. Установлено, что спектры излучения из горячей зоны этой лазерной эрозийной плазмы включают спектральные линии возбужденных атомов меди, индия, селена и их однозарядных ионов. Определены основные фундаментальные параметры и характеристики лазерного факела на основе соединения $\mathrm{CuInSe}_{2}$ : скорость распространения, времена рекомбинации ионов, температуру и концентрацию электронов. Показано, что на начальных этапах существования плазмы основным процессом выступает рекомбинация, а при увеличении расстояния от мишени и времени начинают проявляться газодинамические и тепловые эффекты, которые также в значительной мере будут определять особенности образования атомов и ионов в возбужденных состояниях.

\section{EMISSION CHARACTERISTICS AND PARAMETERS $\mathrm{OF} \mathrm{CuInSe}_{2}$ LASER TORCH PLASMA}

M.P. Chuchman, G.E. Laslov, A.K. Shuaibov, L.L. Shimon

Uzhgorod National University

(46, Pidhirna Str., Uzhgorod 88000, Ukraine;

e-mail: shuaibov@univ.uzhgorod.ua)

$\mathrm{S} \mathrm{u} \mathrm{m} \mathrm{m} \mathrm{a} \mathrm{r} \mathrm{y}$

Radiation spectra and oscillograms of the spectral line intensity of the $\mathrm{CuInSe}_{2}$-based laser erosion plasma are investigated. It is established that the radiation spectra from the hot zone of this laser erosion plasma include spectral lines of excited atoms of copper, indium, and selenium, as well as their singly charged ions. The main parameters and the characteristics of a CuInSe 2 laser torch such as the velocity of propagation, ion recombination times, temperature, and concentration of particles are determined. It is shown that, on the initial stages of existence of the plasma, the dominant process is the recombination, whereas, as the distance from a target and the time increase, the gas-dynamic and thermal effects arise. This determines, to a large extent, the peculiarities of the formation of excited atoms and ions. 